\title{
THE GUILD OF THE POPE'S PEACE: A BRITISH PEACE MOVEMENT IN THE FIRST WORLD WAR
}

\author{
by Youssef TAOUK
}

\begin{abstract}
A little over two weeks after the commencement of the First World War, the Catholic Church was left without its universal shepherd at a time of immense upheaval. Pope Pius X died on 20 August 1914 and immediately, the cardinals of the Catholic Church made their way to Rome to elect his successor. In the conclave, the choice fell on Giacomo della Chiesa, Cardinal Archbishop of Bologna, who took the name of Benedict XV. Della Chiesa had been a student of Cardinal Mariano Rampolla, the Secretary of State under Leo XIII. His essential training had been in diplomacy and this made him well qualified to cope with the war. Immediately upon his accession, Benedict adopted a policy of impartiality and advocated an immediate peace by negotiation. His various peace efforts were ignored, however, and many Catholics in various European countries gave only lukewarm support or made clear an outright rejection of the Pope's pronouncements on diplomacy. This article concentrates on the reaction of British Catholics, in particular, to Benedict XV's peace appeals during the war, including his Peace Note of 1917.
\end{abstract}

The antipathy of leading English Catholics became evident when they manifested complete opposition to a tiny guild, known as the Guild of the Pope's Peace. Although the Guild is mentioned in passing in a number of books and articles on the history of Catholicism in England, ${ }^{1}$ little is known about it and it seems to have been consigned to a limbo of history where so many other 'insignificant' events and organisations have preceded it. This article seeks to shed a ray of light on the nature of the Guild and the reason why it was so vigorously opposed by English Catholics during the Great War. The Guild, faced with insurmountable opposition, condemned by the Catholic hierarchy as well as by most leading Catholic laymen and the Catholic press, did not gain any major influence and eventually fizzled out. But the brief and ineffectual existence of the Guild tells a sad story of the hysteria which held the wider English society in its grip, and Catholics in particular, during the First World War. Far from supporting the Pope's peace efforts, many Catholics seemed to have resented them. Clearly, the Pope's view of the kind of peace that should be established - a negotiated peace-was different to that 
envisaged by many English Catholics. Indeed, the majority of Catholic leaders in Britain appeared to have been opposed to any peace being considered before the complete annihilation of German 'militarism' was achieved. In this, they went so far as to stifle talk of peace within their own ranks.

Benedict XV was from the beginning opposed to the war, morally and intellectually. Unlike some Catholic prelates who depicted it as a just conflict, he rejected it as totally unjustifiable. Seen in this light, it is understandable that only two days after his coronation, on 8 September 1914, the Pope issued a message in which he appealed strongly for a negotiated peace. In this first message, he urged the belligerent leaders to solve their differences by diplomatic means and implored them 'to reflect that this mortal life is already attended with enough misery and suffering as it is'. ${ }^{2}$ For the moment, the Pope could only make appeals; any concrete peace overtures would have been rejected outright.

Less than two months after the first appeal, Benedict issued his much anticipated first encyclical letter, Ad Beatissimi Apostolorum, ${ }^{3}$ on 1 November 1914. As one historian has pointed out, while other European statesmen avoided examining the causes of the war, Benedict proceeded to list them. ${ }^{4}$ He delineated the causes and consequences of the war, blaming the conflict on the absence of mutual love and the neglect of authority as well as antagonism between social classes. In the encyclical, Benedict renewed his call for the rulers of warring nations to resolve their differences without resorting to arms. ${ }^{5}$ From the very outset of his pontificate, therefore, Benedict XV was an advocate of a negotiated settlement.

Arms were not laid aside and the war continued unabated. Benedict was greatly disappointed at the apparent failure of his encyclical to produce fruit. The Pope, however, was not discouraged by his failure; a few weeks after he issued his first encyclical, on 10 January 1915, Cardinal Gasparri published the details of a prayer for peace that had been prepared by the Pope. The prayer asked of the Prince of Peace that: 'in this hour made terrible with burning hate, with bloodshed and with slaughter... may Thy divine Heart be moved to pity'. A letter was sent to the Catholic hierarchy throughout the world by Gasparri, instructing them that it was the Holy Father's wish that every church in Europe should dedicate a Mass to peace on February $7 .^{6}$

However, the governments, and perhaps peoples, of Europe, were not yet ready to listen to talk of peace. Some Catholics among the Allies, particularly in England, were so 'anxious to be accounted full patriots as to wince' at the Pope's encyclical. ${ }^{7}$ They would have preferred him to declare himself for an Allied victory instead.

Despite the failure of his appeals to the Powers to solve international problems by arbitration rather than by resorting to arms, Benedict XV was determined to 'Clama, ne cesses' (Cry out, cease not). ${ }^{8}$ He waited, therefore, until the first anniversary of the war before pronouncing his 
next peace appeal to the belligerents. Allorchè Fummo, the Apostolic Exhortation to the Belligerent Peoples and their Rulers, was issued on 28 July 1915. In his Exhortation, Benedict recounted his previous appeal in $A d$ Beatissimi and noted how it had been rejected. He expressed his determination to devote his energy to reconcile the warring nations. $\mathrm{He}$ implored the leaders of the belligerent parties to end the carnage and reminded them of the responsibility with which they were endowed: 'We adjure you, whom Divine Providence has placed in authority over the nations now at war, to put a final end to this horrible butchery which has been disgracing Europe for a whole year'. ${ }^{9}$ A chillingly accurate prophecy followed the impassioned plea. With insight, Benedict warned the hostile nations of the dire consequences if vanquished nations were subjected to a humiliating peace: 'nations do not die; humbled and oppressed they chafe under the yoke imposed upon them, preparing a renewal of the conflict, and passing down from generation to generation a mournful heritage of hatred and revenge'. ${ }^{10}$ This remarkable prophecy, anticipating by eighteen months Woodrow Wilson's famous 'Peace without Victory' speech of 22 January 1917, put the case clearly for a negotiated settlement as the better outcome.

In Allorchè Fummo, the Pope stretched out his hand and offered it to a continent that had become fixed in the quagmire of a war of attrition. It was in the Vatican's interest that Europe should return to the status quo ante bellum and that the balance of power should be maintained. If the balance of power was lost, then Austria, the last great Catholic power in Europe, might be eliminated and Orthodox Russian power greatly enhanced. ${ }^{11}$ The Entente powers still maintained, however, that if a negotiated peace was concluded in 1915, Germany would retain its military apparatus, a prospect that was unacceptable to the Entente, particularly Britain. The argument against a 'premature peace' prevailed. For this reason, Benedict's outstretched hand was not grasped and even British Catholics received the Pope's proposals without enthusiasm.

The lack of support for the Pope's peace principles among many English Roman Catholics can be discerned in their antagonism to a small ad hoc Catholic organisation which promoted quite specifically the precise formula for peace advocated by Benedict. The skilfully named Guild of the Pope's Peace was founded by Francis Meynell and Stanley Morison ${ }^{12}$ after the introduction of conscription in January 1916. The Guild was composed of a committee of seven people, including two priests, ${ }^{13}$ and was open to all Catholics who were prepared for peace as promoted by the Pope. In a 'Preliminary Notice', issued in early 1916, the Guild explained that the Pope had invited 'all the friends of peace in the world to help Us in hastening the end of the war'. ${ }^{14}$ Catholics could not turn a deaf ear to Benedict's urging. The Notice called on every 'loyal Catholic' to answer Benedict's pleas in order for them to be effective: '[T]he voices of many thousands must speak as one' through the 
Guild of the Pope's peace. ${ }^{15}$ Although the minimum subscription for membership was one shilling, subscribers were encouraged to give more, 'as funds are urgently needed both for Mass offerings and for the effective distribution of the Pope's utterances'. ${ }^{16}$ The Catholic Truth Society (C.T.S.) published the Preliminary Notice in early April 1916 in its Catholic Book Notes (C.B.N.), a monthly journal.

The stated aims of the Guild seemed to stand in stark contrast to the nationalist sentiments of many fellow Catholics. Hence, from the beginning, this small Catholic group was viewed with misgivings by many of the Catholic body, both lay and clerical. E. I. Watkin ${ }^{17}$ recalled more than five decades later that the Catholic hierarchy was putting immense effort into preventing British Catholics from heeding the Pope's pleas for a negotiated peace. Only one bishop, however, went so far as publicly to condemn the Guild - 'not easy, one might suppose, since the Guild... did not preach pacifism but confined itself to the Pope's pleas'. ${ }^{18}$ The bishop who pronounced a public condemnation of the Guild was Ambrose Burton of Clifton. He wrote a letter to the Catholic Times in April 1916, declaring: 'Whatever authority be behind this stop-the-war "Guild"..., it has no sanction or countenance from us, and will receive none, as we trust, from any of our clergy and people.' ${ }^{19}$

Burton's remarks did not go unanswered. J. Hevin, a member of the Guild, addressed a letter to Burton from Newcastle telling the Bishop he was perplexed by his attitude. He informed Burton that there was confusion among the Guild members as to where they had erred, because their objectives were in consonance with Benedict's constant calls for a negotiated peace. Hevin added teasingly: 'Of course, if your Lordship's view is that the Pope's strenuous and ceaseless efforts for peace are ill-timed... then the position you have taken up is perfectly logical'. But he could not believe this to be Burton's position, hence his desire to be enlightened. ${ }^{20}$ It is not known whether this softened Burton's disposition towards the Guild or whether he even replied. But a few months later, Francis Meynell forwarded a copy of A Little Book of Prayers for Peace, which had been compiled by E. I. Watkin for the Guild, ${ }^{21}$ to Burton. In a short, cold letter accompanying the book, Meynell wrote: 'Dear Sir, if your indignation is indeed against the Guild and not against the Pope, it will not be aroused... by the enclosed prayer book which is... duly authorised'. ${ }^{22}$ The book was indeed authorised by Benedict himself and a special blessing was conferred on its compiler, E. I. Watkin. ${ }^{23}$

Most of the other English Catholic bishops, while not condemning the Guild publicly, disapproved of it privately. Evidence suggests that this reached the highest level of authority in that Francis Bourne, the Cardinal Archbishop of Westminster, while prudently refraining from condemning or denouncing the Guild publicly, was privately unhappy at its existence. After the appearance of the Guild's Preliminary Notice, Bourne wrote to 
the Duke of Norfolk requesting that he write a few lines to James Britten, the Secretary of the C.T.S. and editor of Catholic Book Notes. Bourne told the Duke that the Guild had 'no authorization of any kind' and suggested that a few words of remonstrance 'from your Grace to Britten would be helpful in obtaining a disclaimer from the C.T.S, ${ }^{24}$ Norfolk promptly wrote to Britten, who expressed regret for publishing the Guild's work. In expressing his regret, Britten obediently assured the Duke that he would disavow the Guild in the next issue of C.B.N. ${ }^{25}$

Britten had already received strenuous complaints on the same matter from Peter Amigo, the Bishop of Southwark. Amigo had received letters from other prominent Catholics condemning the Guild and he was indignant at the publication of the Guild's pamphlet by the C.T.S. without consultation. ${ }^{26}$ Embarrassed by letters of complaint and the fact that the C.T.S. was located in the see of Southwark, Amigo wrote to the C.T.S. committee. In his letter, he urged a clarification:

While realising the purity of the sentiments of Catholic devotion and loyalty to the Holy See, which animate the promoters of such a Guild, I think that this notice, considering the temper of the Country at the present time, is likely to arouse the gravest misunderstandings, and I am sorry that it seems to come out with the approval of the authorities of this Diocese when I have not been consulted. I am sure that you will agree with me in regretting its being issued. ${ }^{27}$

Amigo received two replies from the C.T.S. expressing unqualified regret that the circular had been enclosed in C.B.N. and promising that the mistake would be rectified in the next issue. ${ }^{28}$ On 29 April 1916, a disclaimer appeared in The Tablet by Britten admitting that he felt it 'to have been a serious error of judgement' to have included the Guild's circular in C.B.N. Britten apologised and announced that it was, of course, necessary to express his regret 'publicly'. ${ }^{29}$

This scarcely edifying incident reveals one of the great paradoxes of the war from the British Catholic perspective. The hierarchical authorities, entrusted with disseminating the Pope's ideals, became staunch opponents of the Guild of the Pope's Peace. On the face of it, it might have been expected that the Catholic hierarchy would have gladly endorsed the formation of a group of Catholics aiming to promote the ideals of Benedict XV, and using his words. But the fear of anything that smacked of 'sedition' in time of war was too great. The fact that the Guild had no authorisation from the hierarchy, and that it was promoting the idea of a negotiated peace, an idea that was contrary to popular sentiments, meant that the Guild could be easily smeared as nothing more than a pacifist movement.

The response to the Guild of the Pope's Peace was part of a larger pattern. The pacifist movement as a whole was clearly anathema to the majority of the Catholic leadership in England during the First World War. The Catholic clergy did not denounce Christian or Catholic pacifists alone. Left-wing radicals and socialists as a whole were continuously 
condemned for their 'unpatriotic' activities and for allegedly weakening the national war effort through their agitation to end the conflict. Sometimes, this opposition was expressed in the most intemperate terms. In one of his frequent articles to the Nineteenth Century, for example, Canon William Barry, the noted theologian and Doctor of Divinity, castigated the so-called 'Liberals' and 'friends of humanity' as veritable traitors. By 'Liberals' and 'friends of humanity', Barry meant the various radical peace activists grouped under the banner of the Union of Democratic Control (U.D.C.) and the Independent Labour Party. He expressed his conviction that, if the Allies lost the war, then these 'peacemongers' would be to blame. They had unceasingly undermined the people's 'patriotism' since war broke out; they had weakened Britain's national spirit and resolve by defending German policy and blaming the Allies for the war. ${ }^{30}$ Barry went on to charge 'those peacemongers' with having 'done all they could to whitewash the Teuton criminal and to break our nerve'. ${ }^{31}$

Other eminent clerics appeared to do their utmost to discredit the peace movement simply by dismissing its adherents as insignificant. Cardinal Bourne, for example, contended that the pacifists were a contemptible, inconsequential minority, simply out of tune with the rest of society. Although the rest of the Catholic hierarchy openly deplored the supposedly baleful influence of the peace movement, Bourne avoided direct condemnation of pacifists and conscientious objectors during the war. While Bourne's position may have seemed mild, in fact he shared the hostility of his brother bishops. In dismissing the peace activists as a minority without influence, it was almost as if he considered them incapable of doing any real harm. In an interview with the Corriere d'Italia in early 1917, the Cardinal merely alluded to the pacifists as people who lived 'in the world of metaphysics'. He assured the Corriere that they had no following either in British society or in parliament and that the British Catholic was in complete solidarity with the government. ${ }^{32}$

Like Cardinal Bourne, some prominent Catholic laymen preferred simply to dismiss peace exponents as irrelevant rather than attribute any importance to them. Hilaire Belloc was one of those who dismissed them as insignificant. In his preface to Cecil Chesterton's The Perils of Peace, Belloc explained he regarded those with pacifist tendencies as 'numerically quite insignificant and utterly out of tune' with the masses. ${ }^{33}$

In contrast to Belloc, other leading Catholic laymen castigated the pacifists strongly and accused them of aiding Germany to the detriment of the Allies. One of the most vociferous opponents of pacifism was Cecil Chesterton, the brother of G. K. Chesterton, who converted to Catholicism in 1913. Chesterton blamed the rise of Prussian militarism on the strengthening of pacifism across Europe in the late nineteenth century. To him, pacifism was not only unchivalrous, but also 'intensely unchristian' ${ }^{34}$ In Chesterton's opinion, pacifism was a variant of 
atheism; that is, it had a materialistic basis and, as he insisted, 'its ultimate appeal is always to dogmas of materialism, ${ }^{35}$

If most prominent Catholics abhorred pacifists and the peace movement in general, they viewed with special horror and contempt Catholic peace advocates and conscientious objectors (C.O.s). This issue became highly controversial after the introduction of conscription in January 1916. Although Cardinal Bourne refrained from either condemning or condoning C.O.s, the Catholic clergy in general condemned them in the strongest terms. An explicit example is shown in the speeches of two parish priests from Tyneside in March 1916. Fr. Joseph P. Byrne, was from St. Bede's Catholic Church in South Shields. He deprecated the C.O. as a coward who sheltered himself behind the men who donned the uniform. Fr. James Bradley of SS. Peter and Paul's Church, Tyne Dock, meanwhile, was still more severe. He held it to be his duty 'to honour those who killed Germans' and revealed that if it were up to him, he would eliminate C.O.s. In his opinion, 'what had happened in Belgium would be repeated in our own country in a degree twenty times worse if the conscientious objector had his own way'. ${ }^{36}$

The clergy's denunciation was matched by hostile speeches on the part of several leading Catholic laymen. Lord Denbigh, for example, poured scorn on C.O.s in the House of Lords in July 1917, declaring that he regarded them as 'a set of despicable people who have no claim to the ordinary rights of citizens and who do not deserve any consideration whatever. ${ }^{37}$ The same degree of anger was shown by Cecil Chesterton who felt enraged that 'these lunatics' were tolerated and permitted to 'exhibit their mental diseases to the astonished eyes of England'. ${ }^{38}$

Most of the Catholic press continually attacked conscientious objectors' beliefs and displayed not an iota of sympathy for their principles. Indeed, when Edward Hicks, the Anglican Bishop of Lincoln, ${ }^{39}$ wrote a letter to The Times defending the genuine C.O. in April 1916, he came under severe criticism from The Universe. In his letter, Hicks asked whether the nation, in its military zeal, was not slipping into the old vices of intolerance and persecution. ${ }^{40}$ The Universe ridiculed Hicks's concern for the way C.O.s were being treated and took exception to his regarding the C.O. as a 'prophet and a visionary'. The paper claimed that the Bishop had written from hearsay and had not studied the facts; if he had, 'it would have been manifest to him that the arguments of the Conscientious Objector are in some cases enough to make the flesh of any sensitive man creep. ${ }^{41}$

In view of the evidence of hostility to conscientious objection, it was always likely that the Guild of the Pope's Peace was at best going to be ignored by most Catholics and at worst excoriated, since its most prominent members were known to be both pacifists and conscientious objectors. One of the most prominent Catholic conscientious objectors, who was also a founding member of the Guild, was Francis Meynell. 
By 1916, Meynell's strident opposition to the war and conscription was causing his father, Wilfrid Meynell, manager of the publishers Burns \& Oates, considerable embarrassment. To extricate his father from an awkward situation, Francis left Burns \& Oates and decided to establish his own printing press. ${ }^{42}$ After his refusal to answer a summons for conscription in August 1916, he appeared before the Marylebone Local Tribunal. $^{43}$ In his autobiography, Meynell intimated that there were several reasons for his conscientious objection. In part, his objection was emotional; he remembered the terrible slaughter of the Boer War and how he wept at the reports of the horrible killing when a little boy. In part, however, it was religious; 'I was... a Roman Catholic and Pope Benedict XV denounced the war'. In part, it was political; he was convinced that the war was between two imperialist powers and that workers were used as canon fodder: 'only for what I considered overwhelmingly good ends - and that for me then would have meant social revolution-would I have supported war and killing', ${ }^{4}$

When he appeared before the Tribunal, Meynell cited his politics but emphasised his religion as his chief motive because religious belief was one of the few reasons generally accepted by the Tribunals weighing claims for conscientious objection. After explaining that the vast majority of fighting soldiers were conscripted and, therefore, not guilty of the war, and that as a soldier he would refuse certain orders, he cited his religious reasons. He told the chairman that, as a Catholic, he heeded the Pope's utterances, and from his central moral position, Benedict XV had clearly said that the war was 'dishonouring humanity'. He had appealed to belligerents to settle the dispute by some other means, as war did not solve problems. Meynell went on to illustrate this, arguing that 'Roman Catholics have a definite system of moral theology... which enables us to look up any point and find what must be considered an authoritative answer'. To corroborate his point, he read two statements from Catholic text-books that confirmed an individual's duty not to fight if that individual was not certain that the war in which he was to fight was just. ${ }^{45}$ When the chairman objected to him citing the Pope and pointed out that popes in the past had waged war themselves, Meynell was quick to retort that he was only referring to the current war, to which the Pope was clearly opposed.

Meynell then produced three written references supporting a claim that he was a sincere C.O. These letters were from prominent Liberal politicians and publicists: James Douglas, the editor of The Star, Charles Masterman, a junior minister in the government, and Eddie Marsh, a personal assistant to Asquith. Marsh wrote:

I can testify that, though in my opinion wrong-headed, [Meynell] is a man of unimpeachable courage and complete sincerity. His attitude as a conscientious objector is of a piece with all his opinions and conduct. But for this kink he would make an excellent soldier. As it is, he would be worse than useless. 
Masterman declared:

I am sure that if there is a genuine conscientious objector in England you are one of the most obdurate kind, and I certainly can testify that these beliefs and determinations of yours are not the creation of a desire to shirk or the results of a natural cowardice. ${ }^{46}$

Even though Meynell was exempted from non-combatant service, he did not receive absolute exemption. ${ }^{47}$ He appealed to the National Tribunal against the decision in September 1916. In his appeal, Meynell produced two more letters: one from H. G. Wells and the other from Lord Lytton. Both disagreed with the defendant's opinions but insisted he was an honest and upright character. However, in the same manner as the Local Tribunal, the Appeal Tribunal exempted him from military service but compelled him to do non-combatant work. This he again refused and, on 29 January 1917, surrendered himself to the authorities and was imprisoned. ${ }^{48}$ In prison, he went on a hunger and thirst strike. On the morning of the twelfth day, he collapsed and was promptly taken to the military hospital where he was told that if he accepted nourishment, he would be discharged unconditionally. He 'nodded and accepted the sweetest drink of my life - a spoonful of peptonised milk' ${ }^{49}$

Publicly, Francis's family disavowed agreement with his actions. A few days after he was imprisoned, The Times reported that Alice Meynell, Francis's mother, had written on behalf of herself and her family to disclaim 'any agreement whatsoever with her son...'. Although she respected Francis's conscience, she held the war to be most just, 'and Germany's crime the greatest crime in history'. ${ }^{50}$ Privately, however, Meynell's family could not but sympathise with his plight. It was around this time that his mother sent him a letter in which she told him she thought him the happiest of her sons, for he was 'so sure and certain'. 51

The ambivalence of the Meynell family reflected the greater division in Catholic thought and outlook regarding pacifism and nationalism. A yawning abyss separated the Catholic pacifist mind from that of the non-pacifist. This is most clearly visible in a letter from Stanley Morison, another founding member of the Guild and a Catholic C.O., to W. A. S. Hewins, the Catholic Conservative member of Parliament for Hereford City, from Wakefield prison in October 1917. Morison had applied for total exemption in February 1916 and on 5 April he had appeared before the Middlesex County Tribunal. In contrast to Meynell, whose objection was both political and religious, Morison's objection was only religious. At his hearing before the tribunal, he expanded on the moral and religious reasons for his objection which were, in his view, integral to the Sermon on the Mount. ${ }^{52}$ As with Meynell, he was granted conditional exemption which he rejected. He was then arrested but refused to obey orders. In his subsequent court martial, he was sentenced to two months hard labour in Winchester prison. ${ }^{53}$ 
The object of Morison's letter to Hewins was to entreat him, as a Catholic, to assist him and some of his fellow C.O.s to obtain a sympathetic hearing of their cases by the government. In writing the letter, Morison expressed penetrating insight into the ideals which separated Catholic pacifists from Catholic imperialists. It is necessary to quote a large portion of the letter to illustrate the conflicting ideologies. After thanking Hewins for a letter he had sent to him, and emphasising the sincerity of his conscientious objection, he wrote:

I am not of course as sure of my C.O. position as of my Catholicism-in the nature of the case there is the difference that I have in the former case only my individual conscience to prescribe my course of action - the Church itself can give me no advice... ${ }^{54}$ Willy nilly $\mathrm{I}$ am an individualist-all conscientious men are. You, for example don't approve the war because Mr. Bonar Law and Lord Lansdowne urged you to stand by France; you approve it because your own conscience and reason move you: you are an individualist therefore. So am I. The difference is this-you have the vast majority of other individualists with you while I am in a very small minority indeed. But the fact of your majority does not legitimise your conscience or illegitimise mine... [W] hen you ask me to die - and you say 'meritoriously' for my country I fear I am obliged to demur because I am sure that the death you would at the present moment consider meritorious would be no real use to that country which I am as anxious as you to serve. On the other hand were I to lay down my life for the principle of pacifism... I do consider that would be 'meritorious' while you would think it waste. Why so? Because we have opposing ideals-yours is the prospect of a prosperous and flourishing British Empire living happily after the present war forced upon it by a wicked competitor. Mine is not this but the prospect of being able to live with a firm purpose to live by what I know to be God's truth. Lest I be led astray by a false or freakish conscience I as a loyal Catholic confer not with the great British public or with his Majesty's Government but with the Catholic Church. I say not with the Government because I am not now a Nationalist or Imperialist ... I learnt to hate national pride and Nationalism, Imperialism and all that love of self because of self which begets the more vulgar forms of patriotism - a longing to see more red on the map. So, the great society to which you truly say I belong, is, for me, the Catholic Church and for you the British Empire and thus you will understand and not think me a prig if I say I should welcome the privilege of dying for the Church or think me a coward if I say I should regard it as a waste to die for the Empire... Do you not see that unless we do make our consciences our own and not the King's we are back to Luther's cuius regio eius religio [each region has its own religion]? [emphasis in original]. ${ }^{55}$

The letter not only demonstrated that a wide ideological gulf separated Catholic pacifists from Catholic imperialists, but it also revealed the essential consideration that maintained this gulf. Morison's direct moral appeal was to individual conscience. The letter indicated that whereas Catholic pacifists held, in conscience, that the war was an imperialist struggle between two equally aggressive empires, Catholic imperialists considered the preservation of the British Empire to be of paramount importance. Morison's concern, as a Catholic C.O., was for an international order 
in which peace was based on justice and love as taught by the Church. Hewins, however, as a British Catholic imperialist, preferred to rely rather on military might to maintain the Empire which he regarded as the supremely beneficent force in the world.

Although such passionate debates between Catholics did not surface frequently in public, they certainly did occur after the inauguration of the Guild of the Pope's Peace. The agitation that the formation of the Guild created among the hierarchy was soon carried from the private into the public arena and Catholic disunity was displayed for all to see. The battlefield was chiefly the Catholic press, especially The Universe, and the protagonists that faced each other were passionate opponents and equally strident supporters of the Guild. The protracted controversy which ensued was triggered by a letter to the editor of The Universe in April 1916, in which the members of the Guild were identified with such pacifists as E. D. Morel, Ramsay MacDonald, and Clifford Allen. Furthermore, the lack of official Catholic episcopal authority for the foundation of the Guild was emphasised. ${ }^{56}$ This gave the founders of the Guild a chance to defend themselves. In the next issue of The Universe, three letters appeared from members of the Guild defending their aims and refuting the charge that the Guild lacked authorisation. The first letter, by an anonymous correspondent, made the point that: "to circulate extracts from the Holy Father's utterances, and to suggest that Catholics should pray, as Benedict XV entreats them..., is not a proceeding that is open to any very serious objection'. It was further argued that the Guild surely did not need 'official sanction' in order to promote the Pope's own statements. $^{57}$

The other two letters are of interest because they were written by members of the Guild's committee and went into greater depth in their defence. E. I. Watkin, the second correspondent, denied any connection with other pacifist organisations such as the No-Conscription Fellowship or the Union of Democratic Control. He pointed out that the Guild's aim was to foster the outcome for which the Pope had been calling all along, not for 'peace at any price' but peace by negotiation. Further, he justified the Guild's legitimacy, arguing that it had the 'highest possible authority', that of the Pope himself. ${ }^{58}$ The differentiation by Watkin between peace at any price and a negotiated peace was of critical importance. It meant that, essentially, the Guild could not be accused of being in league with other 'defeatist' associations whose alleged slogan was 'peace at any price', even that of forgoing all or part of Britain's war aims. The Guild called merely for a negotiated peace which, in effect, made it possible for Britain still to realise some of her war aims, but through negotiation instead of bloodshed.

The third letter was an appeal signed by Fr. William H. Kent O.S.C., Fr. Harold S. Squirrell of the Northampton Diocese and Francis Meynell, the Guild's secretary. It outlined what precisely Benedict had 
said on peace between September 1914 and April 1916, stressing his various entreaties to the warring nations to lay down their arms and pursue peaceful negotiations. 'Surely', the letter reasoned, 'the fact that we do no more than desire to see these appeals and exhortations successful should preserve us from the sneers of Catholics'. In response to the question of whether or not the group had been sanctioned by British Catholic authorities, they replied that the Guild had not sought any such official approval. They reiterated Watkin's assertion that they were in existence in response to an invitation from the Pope himself: 'We invite all the friends of peace in the world to help us in hastening the end of the war [their emphasis]'. It was on this basis alone that the Guild relied for its very existence. The letter concluded with the assurance that 'the Guild is nothing more than a voluntary association of certain Catholics who wish... to take literally to heart the Holy Father's advice about the war'. ${ }^{59}$ This, of course, was to hint that the Guild did not need sanctioning by the Catholic hierarchy in Britain.

Far from dispelling reservations their fellow Catholics may have had regarding the Guild, the correspondence appears to have further raised their ire. For in the next issue, The Universe dedicated its leading article to a vicious denunciation of the Guild. The Universe declared: '[The Guild's] belief borders on heresy; its objects are indistinguishable from those of the "stop-the-war" organisations already in existence'. The paper denounced the Guild's conjectures that since Benedict had implored the belligerents to end the war, every loyal Catholic should support his calls. The Guild's programme was similar to all 'unpatriotic' peace movements created since the beginning of the war. The Universe's objection to the Guild was not only that it was 'an essentially anti-patriotic society', but also that its stance was wrong on Catholic grounds. It objected to a 'few laymen' presuming to act on the Pope's words, and on the basis of what they thought to be his wishes, without the approval of the hierarchy. 'If concerted action on the lines of the Guild ... were necessary ... we may be sure that the Bishops, who... are more likely to be safe interpreters of the Pope's intentions ..., would have taken the appropriate steps'. ${ }^{60}$ Thus, traditional strictures against lay initiatives were invoked.

The newspaper's comprehensive condemnation of the Guild received the hearty endorsement of The Catholic Federationist, the weekly organ of the Salford Catholic Federation, whose president was Bishop Louis Charles Casartelli of Salford. The Federationist found the article in The Universe 'refreshing' and castigated members of the Guild for constituting themselves as interpreters of Benedict's words. It also announced that Catholics were opposed to 'an organisation which begins its career by ostentatiously declaring, by implication, that it has no need of episcopal approval. ${ }^{61}$ Such a harsh charge was unfair to the Guild, as it had never 'ostentatiously' declared such a thing. In their letter to The Universe, Kent, Squirrell, and Meynell had admitted the Guild's existence depended 
on the utterances of Benedict XV. Nonetheless, the 'implication' had been present: in advancing Papal 'approval', the Guild's leaders appeared to argue that they had no need of local episcopal permission.

The lack of official episcopal authorization plagued the Guild and a solution had to be found somehow. For one thing, the Guild's status as a spontaneously created lay initiative was constantly alluded to by the Guild's enemies to discredit it. For another, if the Guild could not convince Catholics that it was legitimate, the Catholic rank and file would eschew it and its influence would remain minimal. The Guild committee, therefore, turned to the one Catholic bishop who had privately expressed some sympathy with it. Frederick Keating of Northampton was the diocesan Bishop of Fr. H. S. Squirrell and thus the Guild had a direct connection with him, since Squirrell was on the Guild's committee. It appears that Squirrell had requested his bishop's help in solving the problem of official authorisation. For on 14 May 1916, Keating wrote to him that they had to be careful how they handled the charge of lack of episcopal authorisation: 'It will not do to say that it [episcopal authorisation] is superfluous because the Pope has invited the faithful to pray', because that was sufficient justification for private devotion only. Since episcopal sanction was required for organised public action sooner or later, Keating advised Squirrell: 'I consider that your defence is that, at present, you are acting individually, testing the feeling of the Catholic Body, and getting in touch with those who are in sympathy' [emphasis in original]. As Keating explained, he understood the Guild's leaders to be proposing that, if the Guild's experiment justified further public action, then the committee would approach the hierarchy. ${ }^{62}$ Whatever the intentions of the Guild's leaders, the strategy was not effected because the Guild's membership remained very small and the 'experiment' failed.

The spring of 1916 represented the high-water mark of the Guild's influence and it gradually faded away as the majority of Catholics remained firmly 'patriotic' in their view of the war. The failure of the Guild scarcely reflects well on the capacity of Catholic leaders to think imaginatively in response to the crisis of war. The Guild, a lay initiative, despite some assistance from two priests, was hoping to mobilise opinion in favour of the ideal of a negotiated end to the war through promoting the Pope's messages. No leading Catholic laymen nor the bishops lent any assistance to the Guild. It was convenient for Catholics to charge the Guild with mischief-making on account of its not having sought episcopal sanction, because this was the most effective way of marginalising it. ${ }^{63}$ Isolating the Guild and stifling its voice would convince the wider British public, which was already accusing Catholics of disloyalty (in the context of the Irish Easter Uprising of 1916), that the Guild was not representative of Catholic opinion. Concern for the reputation of the Catholic Church in Britain appears to have been the primary consideration of the bishops. To have had anything in the nature of a 'pacifist' group in their midst 
was regarded as an embarrassment for Catholics since they had denounced 'pacifist' movements such as the U.D.C. Bishop Keating put it very succinctly when he wrote to Squirrell: 'Public Opinion is in such a highly nervous state that it "smells a rat" in every corner' ${ }^{64}$ Thus, lest silence regarding the Guild might have been considered tantamount to condoning pacifism in their ranks, the episcopate strove to discredit the Guild before it could gain any real influence. The 'patriotic' reputation of the British Catholic Church was believed to be at risk.

After a period of agitation against it, the Guild was effectively stifled. It gained no real influence or power and its statements remained few and far between. Although it adhered firmly to the Pope's advocacy of a negotiated peace, it appears that thereafter, the Guild produced very little material in support of that position. There is little evidence to show that it remained active. One of the very few occasions on which it did take a decisive stand was the launch of the most critical episode of peace diplomacy undertaken by the Vatican during the war-the publication of the Pope's Peace Note in August 1917. ${ }^{65}$

Although a detailed analysis of the reception and interpretation of the Peace Note is not within the scope of this article, it is necessary to give a very brief outline of how it was received in Britain, particularly among Catholics, to understand the context of the involvement of the Guild of the Pope's Peace. Many people in Britain (with the exception of pacifists and radicals) either viewed the Peace Note with suspicion or rejected it outright. The Pope's own flock received the Note with some discomfort. Most leading British Catholics were not yet ready to support a negotiated peace but could not repudiate openly the Pontiff's peace offer. Thus, publicly, many leading Catholics, as well as the Catholic press, attempted to defend the peace move against its more strident Protestant or secular critics. ${ }^{66}$ Some Catholic newspapers, however, showed public reserve in accepting the Note. The Universe, for example, appeared to be quite unsympathetic to the peace offer. It observed that no one should be surprised if the Pope's peace proposals were not accepted as they stood and even went so far as to declare that 'nothing will be lost' if the initiative failed. ${ }^{67}$ Of more significance was The Tablet's reaction. While approving some of the terms proposed by the Pope, The Tablet rejected the Note in no uncertain terms. It was only fair, the Catholic weekly reasoned, that the Pope's Peace Note be judged on the assumption that the Allies could not attain complete victory. But such an assumption, the paper added, was not shared by the British 'and certainly not by anyone connected with this journal'. ${ }^{68}$ Since non-Catholics saw The Tablet as the mouthpiece of Catholics in Britain, others had every right to conclude that, whatever might be said in defence of Benedict and his motives, Britain's most prominent Catholics had rejected the Note.

This conclusion was buttressed by the man at the highest level of authority among English Catholics. Cardinal Bourne complemented 
The Tablet in its determination to achieve peace through victory. $\mathrm{He}$ publicly expressed his disagreement with the Pontiff's Peace Note and his commitment to British war aims when he declared, shortly after the Note was released:

The Pope has proposed that all the belligerents should come to a compromise. No! We demand the total triumph of right over wrong. We do not want a peace which will be no more than a truce or armistice between two wars. There may be in our land some people who want peace at any price, but they have no following among us. We English Catholics are fully behind our war leaders. ${ }^{69}$

While speaking for his flock in England, Bourne had apparently either forgotten, or chosen to ignore, the thorn that was the Guild of the Pope's Peace in the side of the 'patriotic' Catholic body. For soon after, the Guild printed a booklet reviewing the history of papal peace diplomacy down the centuries, offering a thesis boldly contradicting Bourne's confident assertion. The booklet scolded Catholics for their rejection of Benedict's attempt to mediate between the belligerents. It enquired accusingly:

How is it that even now, after the Pope's proposal of terms which would secure all the finer objects for which our politicians claimed to be fighting, and for which the masses of our soldiers are indeed fighting, there are many Catholics who still reject the Holy Father's mediation? Not only do they reject it, but... seeking to invent new 'war aims' when the old are in danger of realisation, many endure in silence, some even approve, the calumnies of the war press against the Holy Father. ${ }^{70}$

This stark contradiction, which clearly showed that not all Catholics were fully behind their war leaders, must have disconcerted Bourne. This in itself, of course, demonstrates the chief reason behind the hierarchy's determination to denounce the Guild: the Guild advertised the fact that not all Catholics were quiet, consenting and compliant 'patriots' as the hierarchy wished to assert.

In addition, the Guild produced another pamphlet in late 1917 in support of the Pope's efforts to abolish military conscription. In his ensuing correspondence in support of the Peace Note, Cardinal Gasparri, the Secretary of State to the Holy See, wrote a letter on 28 September 1917 to David Lloyd George, the British Prime Minister. The letter, which was publicly released shortly after it was sent, denounced conscription as the 'cause of innumerable evils'. It explained how the Pope intended to achieve permanent peace by the reciprocal disarmament of the nations. It repeated Benedict XV's assertion, already emphasised in the Peace Note, that there was only one practical method of attaining disarmament, namely, 'that the civilised nations ... should agree upon the simultaneous and mutual abolition of compulsory military service'. The letter cited prewar Britain and the U.S. as examples of the fact that voluntary military service was sufficient for the maintenance of public order, while not supplying the dangerous manpower that would 'furnish the enormous 
armies demanded by modern warfare'. Once conscription was suppressed, the letter continued, reciprocal disarmament would follow automatically, accompanied by a lasting peace. ${ }^{71}$

The recommendations were given scanty attention and no support by the Foreign Office. In addition, Catholics gave them little consideration. As D. Hayes has accurately observed, even the Catholic bishops did not receive the proposals with much enthusiasm. As for the Catholic laity, Hayes expressed it quite succinctly when he asserted that 'the action of their spiritual Head cut across all the national emotions and prejudice of the time'. ${ }^{72}$

The Guild of the Pope's Peace, however, remained true to its objective of disseminating and promoting Benedict's utterances for peace. The Guild was one of a very minute number of Catholic organisations that manifested their support for Gasparri's letter. The Guild produced a small pamphlet entitled 'The Pope's Plan for the Destruction of Militarism', in which it endorsed the Pope's basis for the abolition of conscription. The pamphlet argued that militarism could only be eliminated through general disarmament and the eradication of conscription, emphasising that Britain must first adopt the idea herself and make it her 'sole' war aim. ${ }^{73}$ Apart from the Guild's promotion of the Pope's formula to achieve permanent peace, there is nothing to suggest other leading Catholics reacted positively to this fresh initiative from their spiritual head in the autumn of 1917.

It appears that after late 1917, the tiny Catholic peace organisation ceased to be active. In the inter-war years and well after the Second World War, some of its members continued to be involved in other peace movements and to convey an interest in the politics of the Great War. E. I. Wakin, for example, became a staunch pacifist in the 1930s and was among the founders of Pax, the Association for the Promotion of Peace, in 1936. Stanley Morison retained an interest in the First World War, contributing a major essay in the 1950s on Anglo-American relations in 1917. ${ }^{74}$ However, whereas Morison and Watkin remained Catholics and found solace in their Catholicism until the end of their lives, Francis Meynell became disillusioned with his faith soon after the conclusion of war. By the early 1920s, he had left the Catholic Church and become a communist. One cannot help but wonder whether the Catholic leadership's pungent treatment of the Guild and its members may not have contributed to Meynell's disillusionment with the Catholic Church. True, in its brief but tumultuous life the Guild had defied the nationalistic outlook of other English Catholics, but the latter had refused even to consider the reason for its existence. On the contrary, they had regarded the Guild's activities as subverting efforts to support the war. The Guild, therefore, had to contend with an onslaught of criticism. However, to its credit, the Guild remained faithful to the peace utterances and policies of Pope Benedict XV to the end. Some of 
the Guild's members were condemned because of their pacifist leanings. In their critics' eyes, the activists of the Guild threatened to spoil the carefully cultivated image of British Catholics as a firmly 'patriotic' body whose loyalty could not be questioned. As a consequence, prominent Catholics formed a phalanx of opposition to the Guild and tried to discredit it as nothing more than an insignificant and illegitimate lay initiative without authority, and certainly without sanction from the Catholic hierarchy. In doing this, British Catholics who condemned the Guild were in effect also implicitly distancing themselves from the Pope's efforts to bring about negotiated peace. In fact, most prominent British Catholics displayed clear discomfort in the face of Benedict XV's eloquent peace appeals.

\section{ABBREVIATIONS}

$\begin{array}{ll}\text { C.B.N. } & \text { Catholic Book Notes } \\ \text { C.O. } & \text { Conscientious Objector } \\ \text { C.T.S. } & \text { Catholic Truth Society } \\ \text { Meynell } & \text { F. Meynell, My Lives, London: The Bodley Head, 1971. } \\ \text { Rope } & \text { H. E. G. Rope, Benedict XV: The Pope of Peace, London: John Gifford, } 1941 . \\ \text { S.M.P. } & \text { Stanley Morison Papers, Cambridge University Library, Manuscripts Department. } \\ \text { U.D.C. } & \text { Union of Democratic Control }\end{array}$

\section{NOTES}

1 M. Snape, for example, refers to the Guild of the Pope's Peace in one brief sentence in his article, 'British Catholicism and the British Army in the First World War', Recusant History, 26(2), (Oct. 2002), p. 329. S. Gilley also mentions the Guild in passing in 'The Years of Equipose, 1892-1943' in V. A. McClelland and M. Hodgetts (eds.), From Without the Flaminian Gate (London: Darton, Longman and Todd, 1999), p. 45. The latest article to cite the Guild of the Pope's Peace appeared in The Tablet on 20 Aug. 2005, p. 16. The article, written by Barbara Wall, was a personal reflection on the eight papacies from Pope Benedict XV.

2 Quoted in A. Rhodes, The Power of Rome in the Twentieth Century: The Vatican in the Age of Liberal Democracies, 1870-1922, (London: Sidgwick \& Jackson, 1983), p. 227. See also Rope, p. 56.

3 The full text of Ad Beatissimi is contained in The Pope and the People: Select Letters and Addresses on Social Questions (London: Catholic Truth Society, 1932), pp. 202-217. An interpretation of the encyclical is given in J. F. Pollard, The Unknown Pope: Benedict XV (1914-1922) and the Pursuit of Peace (London: Geoffrey Chapman, 1999), pp. 86-87.

4 D. R. Zivojinovic, The United States and the Vatican Policies, 1914-1918 (Colorado: Colorado Associated University Press, 1978), p. 26.

5 Rope, p. 60.

6 A copy of the letter to the hierarchy is found in Archbishop Whiteside's Letter to the Clergy, 29 Jan. 1915, SI, VII, C/2, Whiteside Papers, Archdiocese of Liverpool. A complete copy of the Pope's prayer for peace is contained in W. H. Peters, The Life of Benedict XV (Milwaukee: Bruce Publishing Company, 1959), p. 123.

7 Rope, p. 68.

8 Ibidem, p. 71. The phrase was used by Benedict XV in his allocution to the Sacred College on Christmas Eve, 1914.

9 Ibidem, pp. 88-90. A full translation of the Exhortation was given in The Tablet, 7 Aug. 1915 , p. 177.

10 H. W. Flannery (ed.), Pattern for Peace: Catholic Statements on International Order (Westminster: The Newman Press, 1962), p. 9. Writing twenty years later, J. Eppstein 
testified to Benedict's insight. Two years after Hitler came to power, Eppstein wrote that no one who saw the rearming of Germany could deny that Benedict XV 'knew human nature only too well...' For he had predicted 'after the first year of the war this tragic alternative to the peace for which he pleaded'. J. Eppstein, Must War Come? (London: Burns Oates \& Washbourne, 1935), pp. 13-14.

11 It seems that the Pope was obsessed with the rise of Russian power if the Allies won the war. According to J. D. Gregory, the secretary of the British Mission to the Vatican: 'Benedict XV had one obsession-Russia. In all the conversations I have had with him, he can never keep off the subject. Even the fear of another Kulturkampf, if Germany wins the war, pales in his eyes before the spectre of a Russian victory, and Russian troops on the Bosphorus'. Quoted in A. Rhodes, op. cit., p. 228.

12 Francis Meynell was the son of Wilfrid and Alice Meynell. His father was the manager of Burns \& Oates where Francis worked after 1909. He leaned towards left-wing politics. For his autobiography, see Meynell. Stanley Morison converted to Catholicism in December 1908 and in 1913 was introduced to Wilfrid Meynell and employed at Burns \& Oates. He was placed with Francis Meynell who was in charge of book design. The two became close friends and they both refused enlistment for military service in 1916. For a biographical sketch, see Stanley Morison: A Portrait (London: Trustees of the British Museum, 1971). S. Gilley, in 'The Years of Equipoise', op. cit., erroneously states that the Guild was founded by E. I. Watkin and Wilfrid Meynell (p. 45). E. I Watkin may have been a cofounder along with Francis Meynell and Stanley Morison, but Wilfrid Meynell was definitely not involved with the Guild since he was an avid war supporter.

13 Meynell, p. 90. The committee was made up of Francis Meynell, who was also the secretary of the Guild, Stanley Morison, J. F. L. Bray, Christopher St. John, E. I. Watkin, Fr. W. H. Kent, and Fr. H. S. Squirrell.

14 Quoted from the Pope's Exhortation of July 28 in the Preliminary Notice of the Guild of the Pope's Peace, [April 1916], Box 24, P IV, S.M.P. See also Rope, p. 89.

15 Preliminary Notice of the Guild of the Pope's Peace, [April 1916], Box 24, P IV, S.M.P. It was clearly stated that the Guild's aim was 'to help now towards the making of the Pope's Peace. For the achievement of this end the Guild will press for the Holy Father's own suggested methods - methods which, indeed, he calls "the only way".' These were: 1) a truce; 2) a declaration of conciliatory peace terms; and 3) an immediate conference. 'Only the Pope's Peace, a spiritual peace, can be either holy or permanent; for any other will be founded on militarism, vengeance, force, and worldly ambitions'.

16 Quoted in N. Barker, Stanley Morison (London: Macmillan, 1972), p. 63.

17 E. I. Watkin converted to Catholicism in 1908 and was a member of the Guild of the Pope's Peace. He adopted a pacifist approach to war and was a non-combatant in World War I. He was vehemently opposed to conscription. See, for example, his The Crime of Conscription (London: James Clarke, 1939).

18 Letter written in 1968 by E. I. Watkin, quoted in N. Barker, op. cit., p. 63.

19 Quoted in the Catholic Times, 28 Apr. 1916, p. 4.

20 J. Hevin to Bishop Burton, 8 May 1916, Folder 1915-1916, Burton Papers, Archives of the Diocese of Clifton.

21 E. I. Watkin, A Little Book of Prayers for Peace (London, 1916). The small book of prayers was compiled for the purpose of entreating God to end the scourge of war.

22 Francis Meynell to Burton, 9 Sep. 1916, Folder 1915-1916, Burton Papers. Note the 'Dear Sir' instead of 'My dear Lord' or 'Your Lordship', the customary address to a bishop.

23 See booklet entitled 'The Pope \& the War', 1917, Box 24, P IV, S.M.P.

24 Bourne to the Duke of Norfolk, 18 Apr. 1916, Box: Nov. 1915-June 1916, Folder: April 1916, 15th Duke of Norfolk Papers, Arundel Castle Archives.

25 James Britten to the Duke of Norfolk, 21 Apr. 1916, Box: Nov. 1915-June 1916, Folder: April 1916, 15th Duke of Norfolk Papers.

26 See, for example, letters from Herbert Dean to Bishop Amigo, 12 Apr. 1916, and W. Marchant to Amigo, 24 Apr. 1916, Box: 1st World War: Involvement of Diocese in Various Home Activities-The Guild of the Pope's Peace, Amigo Papers, Diocesan Archives of Southwark. While Marchant, in a strongly worded letter, urged Amigo to condemn the Guild with the rest of the hierarchy, Dean, the editor of The Universe, wrote that he was shocked to receive a copy of C.B.N. "in which was inserted a seditious pamphlet in which certain Catholics call upon us to join in an effort to "stop the war", and assert, equivalently, that the Nation does not know what it is fighting for! These people... endeavour to entangle the Catholic body in their doings'. He hoped that they would be 'promptly and officially disavowed' because they could undo all the trust which the government put in Catholics.

27 Amigo to Fr. Paine, 13 Apr. 1916, Box: 1st World War: Involvement of Diocese in Various Home Activities - The Guild of the Pope's Peace, Amigo Papers. 
28 A. Ross to Amigo, n.d. [Apr. 1916], and Britten to Amigo, 21 Apr. 1916, Box: 1st World War: Involvement of Diocese in Various Home Activities - The Guild of the Pope's Peace, Amigo Papers.

29 The Tablet, 29 Apr. 1916, p. 567.

30 W. Barry, 'False and True Idealism in the War', Nineteenth Century, 83(495), (May, 1918), p. 913

31 Ibidem, p. 916.

32 The Tablet, 17 Feb. 1917, p. 218. Cardinal F. A. Bourne, 'Union Sacrée': Great Britain in Wartime (London: Burns \& Oates, 1917), p. 6.

33 C. Chesterton, The Perils of Peace (London: T. Werner Laurie, 1916), pp. 16-17.

34 C. Chesterton, The Prussian Hath Said in His Heart (London: Chapman Hall, 1914), p. 67.

35 Ibidem, p. 68.

36 Quoted in The Tablet, 1 Apr. 1916, p. 428.

37 House of Lords Debates, vol. 25, col. 857.

38 C. Chesterton, The Perils of Peace, p. 82.

39 Bishop Hicks was the president of the Church of England Peace League, which was founded in 1910. A. Marrin, The Last Crusade: The Church of England in the First World War (North Carolina: Duke University Press, 1974), p. 65.

40 The Times, 4 Apr. 1916, p. 9.

41 The Universe, 7 Apr. 1916, p. 3.

42 J. Dreyfus, A History of the Nonesuch Press (London: Nonesuch Press, 1981), p. 9. The press he established after leaving Burns \& Oates was the Pelican Press.

43 Local Tribunals were district tribunals that heard and determined the cases of local conscientious objectors. Appeal Tribunals in specified areas decided the cases of those rejected by the Local Tribunals. Finally, the Central Tribunal was the highest authority in deciding appeals. An appeal to the Central Tribunal required the permission of the Appeal Tribunal concerned.

44 Meynell, pp. 93-94.

45 Ibidem, p. 95.

46 C. E. Playne, Society at War, 1914-1916 (London: Allen \& Unwin, 1931), pp. 278-279.

See also Charles H. Masterman to F. Meynell, 15 Aug. 1916, Box 24, C.O. Letters (Stanley Morison Papers, Cambridge University Library (MSS. Dept.)) - 1916-1917, S.M.P.

47 Local Tribunals came under increasing criticism for not granting exemptions. On 29 February 1916, Philip Snowden, a member of the Independent Labour Party, condemned the way local tribunals were treating C.O.s. He cited the case of a man who had gone before the tribunals and defended his case convincingly, yet was not exempted from military service. 'I want to know what would satisfy a tribunal that the man had a conscientious objection'. House of Commons Debates, vol. 80, col. 947. Likewise, in his introduction to I Appeal Unto Caesar, Gilbert Murray cited two faults in Local Tribunals: 1) they did not have the necessary qualifications to deal with the minds of intellectual and religious men; and 2) they were eager to satisfy the War Office and the press. M. Hobhouse, I Appeal Unto Caesar (London: Allen \& Unwin, [1917], p. vii. Tribunal proceedings are described in chapter 5 of D. Boulton. Objection Overruled (London: Macgibbon \& Kee, 1967).

48 Meynell, p. 99.

49 Ibidem, p. 102. Meynell later wrote a lengthy article about his experience as a C.O. in prison. It was to be published in the Daily Herald but this never eventuated. A draft of the article is in Box 24, C.O. Letters-1917-1918, S.M.P.

50 The Times, 1 Feb. 1917, p. 3.

51 Alice Meynell to Francis Meynell, undated [Feb. 1917], Box 24, C.O. Letters-1916-1917, S.M.P.

52 N. Barker, op cit., p. 68.

53 Ibidem, p. 72.

54 Presumably, Morison is here referring to the English Catholic hierarchy, for the Pope clearly had given advice.

55 Stanley A. Morison to Hewins, 19 Oct. 1917, Hewins 66/107, Hewins Papers, Sheffield University Library, Special Collections.

56 The Universe, 28 Apr. 1916, p. 4. The correspondent was W. S. Marchant.

57 Ibidem, 5 May 1916, p. 4.

58 Ibidem. It is important to note that by implying this, Watkin did not mean that the Pope had officially sanctioned the Guild, since he could not do so. Watkin was referring to Benedict's appeal to Catholics to pray for peace. In this regard, the Guild was only doing what the Pope had asked Catholics to do and thus, had his 'authority' only indirectly.

59 Ibidem, p. 5. The quotation of Benedict XV was taken from Allorchè Fummo, his Exhortation of 28 July 1915. 
60 The Universe, 12 May 1916, p. 1.

61 Catholic Federationist, June 1916, p. 5.

62 Bishop Keating to Fr. H. S. Squirrell, 14 May 1916, Box 24, P IV, S.M.P.

63 In assessing the reaction to the Guild of the Pope's Peace, it is worth remembering that the lingering after-effect of the modernist crisis of the previous decade may still have played a rôle in the hierarchy's opposition to the Guild. Modernism was condemned in the papal encyclical Pascendi, which was published in September 1907. For the modernist controversy, see L. F. Barmann, Baron Friedrich Von Hügel and the Modernist Crisis in England (Cambridge: Cambridge University Press, 1972) and N. Sagovsky, 'On God's Side': A Life of George Tyrrell (Oxford: Clarendon Press, 1990), chapters 12-14.

64 Bishop Keating to Fr. Squirrell, 14 May 1916, Box 24, P IV, S.M.P.

65 A full copy of the text of the Pope's Peace Note is found in S. Z. Ehler and J. B. Morall (eds.), Church and State Through the Centuries: A Collection of Historic Documents with Commentaries (London: Burns \& Oates, 1954), pp. 371, 374-3 77.

66 See, for example, the Catholic Times, 24 Aug. 1917, p. 3 and the Catholic Herald, 25 Aug. 1917 , p. 4

67 The Universe, 17 Aug. 1917, p. 1.

68 The Tablet, 18 Aug. 1917, p. 196.

69 Quoted in A. Rhodes, op. cit., p. 242.

70 'The Popes and Peace' (p. 3), [Nov. 1917], Box 24, P IV, S.M.P.

71 Cardinal Pietro Gasparri to Lloyd George, 28 Sep. 1917, F.O. 37 1/3084/17, The War Files (Political), Public Record Office, Kew Gardens, London. The letter is also cited by H. W. Flannery (ed.), op. cit., pp. 11-12.

72 D. Hayes, Conscription Conflict (London: Sheppard Press, 1949), p. 283.

73 'The Pope's Plan for the Destruction of Militarism', [Nov. 1917], Box 24, P IV, S.M.P.

74 S. Morison, 'Personality and Diplomacy in Anglo-American Relations, 1917' in R. Pares and A. J. P. Taylor (eds.), Essays Presented to Sir Lewis Namier (London: Macmillan, 1956), pp. 431-474. 